\title{
Research on achieving a meteorological monitoring system to increase efficiency in the execution and operation of solar installations and to reduce environmental pollution
}

\author{
DOI: $10.35530 / I T .070 .01 .1268$
}

NICOLAE DIACONU

ANDREEA ROXANA UNGUR (POPESCU)
MARIN SILVIU NAN

DANUT GRECEA
OLIMPIU STOICUTA

MARIUS RAZVAN POPESCU

\section{REZUMAT - ABSTRACT}

Cercetări privind realizarea unui sistem de monitorizare meteorologică pentru creșterea eficienței în execuția și exploatarea instalațiilor solare și pentru reducerea poluării mediului

Protecția mediului alături de economie și coeziunea socială sunt principalii piloni în dezvoltarea durabilă a unei țări. În acest context, strategia de dezvoltare a sectoarelor industriale din România trebuie să promoveze tehnologiile moderne cu un impact cât mai redus asupra mediului. Prin urmare, stabilirea modului de dispersie a poluanților, cât și identificarea fenomenelor meteorologice ce produc stagnarea poluanților în atmosferă, reprezintă o necesitate în cadrul zonelor industriale. Pe de altă parte, creșterea eficienței conversiei fotovoltaice, prin mărirea gradului de utilizare a radiației solare, atât din punctul de vedere al execuției, cât și al exploatării instalațiilor fotovoltaice, poate fi realizată în urma unor analize amănunțite asupra parametrilor și fenomenelor meteorologice ce definesc zona în care urmează a fi amplasat parcul fotovoltaic. Astfel, în cadrul acestui articol se prezintă un sistem meteorologic compus din șase stații meteorologice și un computer destinat salvării datelor achiziționate. Fiecare stație meteorologică achiziționează, din locul unde este montată, informații cu privire la următoarele variabile: temperatura mediului, intensitatea radiației solare, umiditate, presiune barometrică, altitudine, viteza vântului, direcția vântului și cantitatea de precipitații.

Cuvinte-cheie: protecţia mediului, sistem meteorologic, radiaţie solară

\section{Research on achieving a meteorological monitoring system to increase efficiency in the execution} and operation of solar installations and to reduce environmental pollution

Environmental protection alongside the economic and social cohesion are key pillars in the sustainable development of a country. In this context, the strategy of development of industries in Romania should promote modern technologies with as reduced environmental impact as possible. Therefore, determining how dispersion of the pollutants and identify weather events that cause the stagnation of pollutants in the atmosphere are a necessity in the industrial areas. On the other hand, the increased photovoltaic conversion efficiency by increasing the use of solar radiation, both in terms of execution as well as the operation of photovoltaic installations can be achieved as a result of detailed analysis of parameters and meteorological phenomena that define the area where the photovoltaic park will be located. Thus, this article presents a weather system consisting of six weather stations and a computer for keeping the data acquired. Each weather station acquires from where is assembled, information on the following variables: ambient temperature, solar radiation intensity, humidity, barometric pressure, altitude, wind speed, wind direction and rainfall.

Keywords: environmental protection, meteorological system, solar radiation

\section{INTRODUCTION}

The pollutants mode dispersion in the atmosphere is influenced by meteorological phenomena and parameters in the area where the pollution source is located. To find the best methods to minimize the quantities of pollutants released into the environment, the sources of pollution must be continuously monitored [1].

On the other hand, to increase the photovoltaic conversion efficiency by increasing the use of solar radiation, both in terms of execution as well as the operation of photovoltaic systems, requires a thorough analysis of the parameters and meteorological phenomena that define the area where the photovoltaic park will be located.

In this context, the paper presents the design of a system of six meteorological weather stations and a central computer for saving the acquired data.
The Meteorological System presented in this article is intended for continuous monitoring of meteorological parameters in the industrial areas that are sources of pollution in the areas where the photovoltaic parks will be located.

The meteorological stations acquire, from where they are located, information on the following variables: ambient temperature, solar radiation intensity, humidity, barometric pressure, altitude, wind speed, wind direction and rainfall.

\section{DESCRIPTION OF THE METEOROLOGICAL SYSTEM}

The Meteorological system proposed consists of six weather stations and a computer. Data transmission between system components meteorological 7 is via GSM modems. Each weather station acquires information on the following variables: ambient temperature, 
solar radiation intensity, humidity, barometric pressure, altitude, wind speed, wind direction and rainfall. The parameters listed above are taken using specialized sensors that are connected to a Arduino Uno development platform, and then via a GSM modem are transmitted to the personal computer, where these parameters are stored.

In the meteorological system architecture shown in figure 1, the personal computer acts as a master device, while the other six meteorological stations play the role of SLAVE type devices.

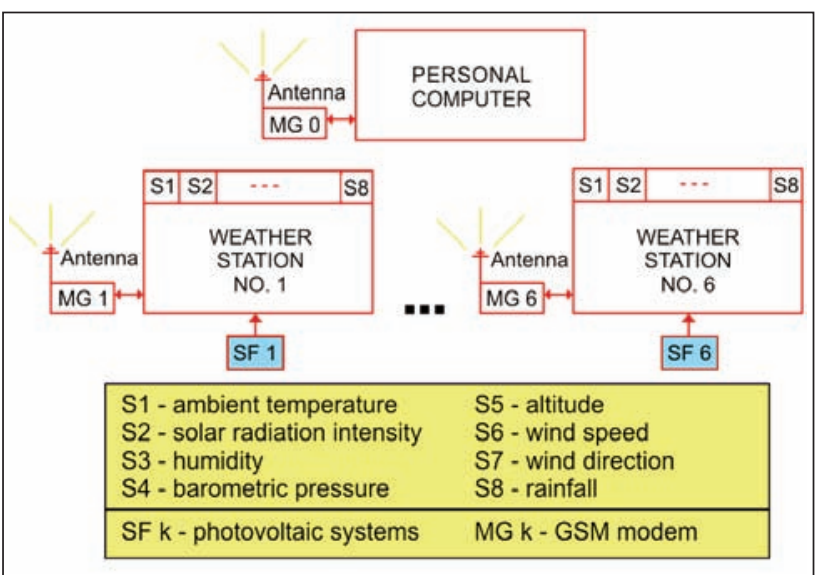

Fig. 1. The Architecture of the Meteorological System

The data reading provided by the meteorological stations it is made in an order initially set via the acquisition program running on the personal computer (PC).

Each modem has in its part a phone card with a phone number.

The exchange of information between personal computer and the composition of the modem from the weather stations is made via short message service (SMS).

The personal computer is powered from the mains power supply of 220 Vac through a backup power system.

Each station is has autonomous energy. The electricity supply units with equipment from the composition of a meteorological station are via an autonomous photovoltaic system with energy storage, where the consumers have continuous current.

The main elements of the composition of autonomous photovoltaic systems are described below.

\section{THE PHOTOVOLTAIC SYSTEM}

The block diagram of a photovoltaic system is shown in figure 2.

The photovoltaic system is made up of a photovoltaic panel TPS-103, a charge controller and a battery.

All photovoltaic system from the 6 meteorological stations are identical.

The photovoltaic panel TPS-103, used in the photovoltaic system is one of amorphous silicon, with a maximum output of $6 \mathrm{~W}$ [2].

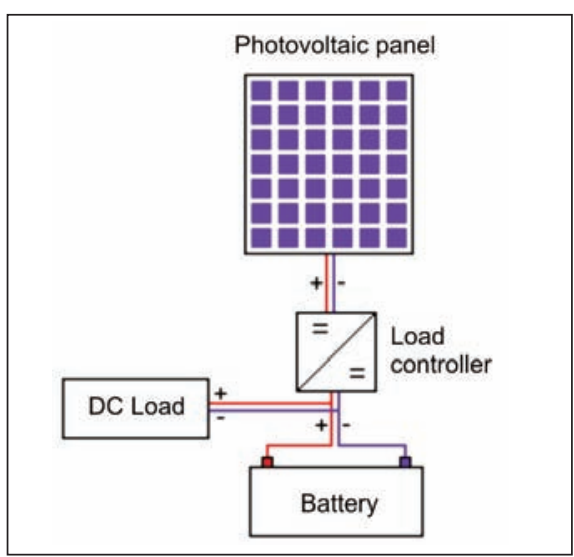

Fig. 2. Block diagram of the photovoltaic system

Current - power and voltage - the voltage of the photovoltaic panel TPS-103 characteristics are shown in figures 3 and 4.

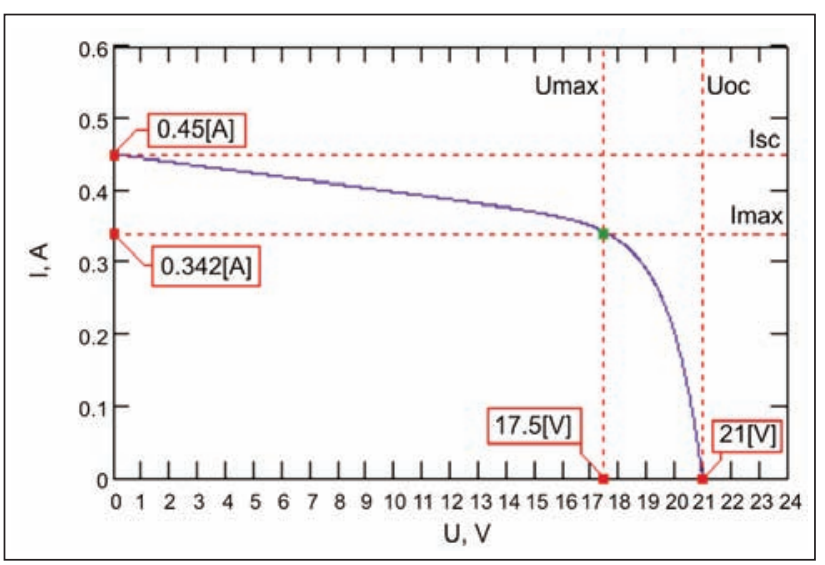

Fig. 3. Current-voltage of the photovoltaic panel TPS-103 characteristic

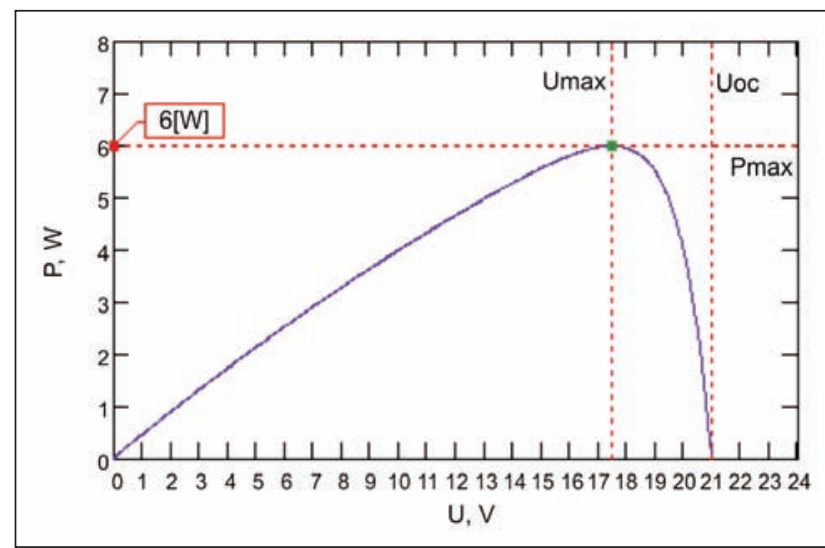

Fig. 4. Power-tension of the photovoltaic panel TPS-103 characteristic

The characteristics shown in figuress 3 and 4 are obtained in Mathcad, based on electrical parameters of the TPS-103 photovoltaic panel, supplied by the manufacturer company.

The load controller used in the photovoltaic system is Conrad 12 V/4 A. The load regulator is one type 
series that aims to make the energy flow within the photovoltaic system.

The load controller controls the battery charging current, so the voltage across the battery voltage does not exceed the maximum load.

Among the most significant technical data of the Conrad load controller, we mention here the following [3]: the nominal voltage is $12 \mathrm{~V}$, the maximum battery charging voltage is $13.8 \mathrm{~V}$, the maximum current of photovoltaic panel and maximum battery charging current is $4 \mathrm{~A}$ and maximum power consumption of the controller load is $1.5 \mathrm{~mA}$.

On the other hand, the battery constituting the photovoltaic system is S12 / 6.6S, type Pb - gel.

Among the most significant technical data of the battery [4], it is noted the following: the nominal voltage across the battery is $12 \mathrm{~V}$, nominal capacity $6.6 \mathrm{Ah}$ and the discharge current is $0.06 \mathrm{~A}$. The variation in proportion to the time of the discharge current of the battery is defined by the following relation:

$$
i(t)=a_{1}+a_{2} \cdot t+a_{3} \cdot e^{a_{4} \cdot t}
$$

where: $a_{1}=0.397186 ; \quad a_{2}=-0.003356$;

$$
a_{3}=3.641273 ; a_{1}=-0.374555 \text {. }
$$

Equation (1) is obtained from the technical data of the battery using the exponential regression. The variation in proportion to time of the discharge current of the battery is shown in figure 5 .

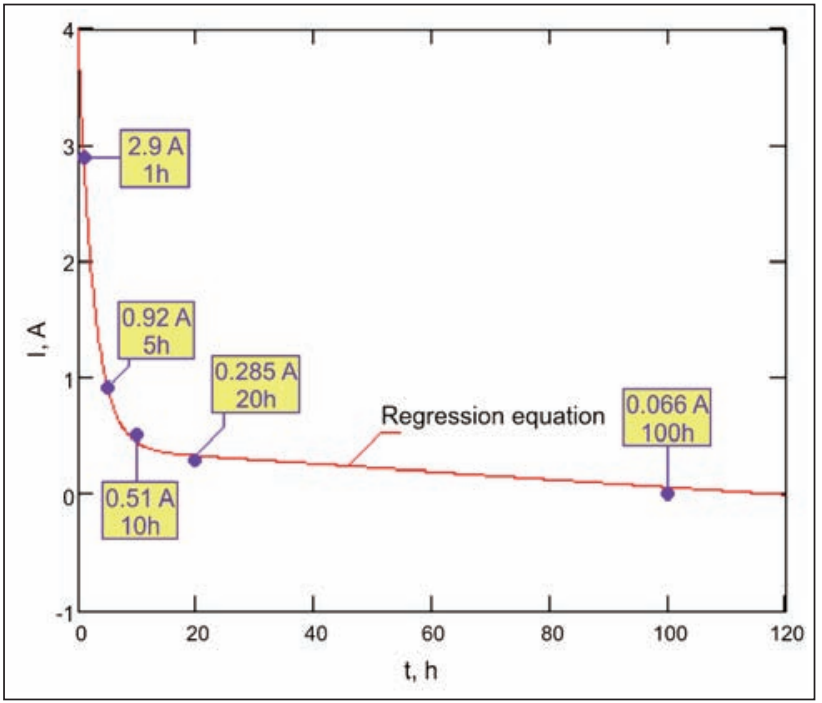

Fig. 5. The variation in proportion to time of the discharge current

According to technical specifications, battery S12/S 6.6 is designed to support up to 800 full discharge cycles (100\%) and 3000 cycles of discharge of $30 \%$.

\section{DATA ACQUISITION SYSTEM}

The data acquisition in the composition of meteorological stations is built around the development platform Arduino Uno, and eight sensors that aim to measure the following quantities: ambient temperature, solar radiation intensity, humidity, barometric pressure, altitude, wind speed, the wind direction and the amount of rainfall.

All sensors except the anemometer, rain gauge, wind vane and the pyranometer are placed in a metal box fitted with side holes. All items listed above, plus photovoltaic system and GSM modem, forms the basic structure of a weather station. The meteorological station is shown in figure 6 .

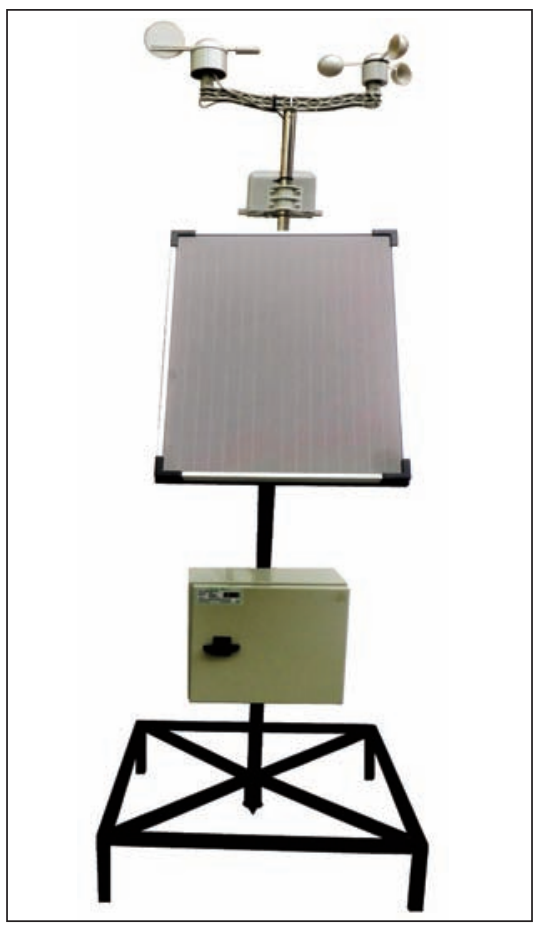

Fig. 6 . The meteorological stations

In the metal box in addition to those mentioned above, are mounted the battery and the load controller from the composition of the photovoltaic system.

The Arduino Uno Development Platform is a system built around the microcontroller ATMega328P.

The main features of the platform Arduino Uno platform are: the voltage of the platform is the range $7 \mathrm{Vdc}-12 \mathrm{Vdc}$, the total number of digital inputs and outputs are 14, of which 6 are PWM outputs, the platform has 6 analog inputs, has a Flash memory of $32 \mathrm{~KB}$, a SRAM memory of $2 \mathrm{~KB}$, EEPROM memory of $1 \mathrm{~KB}$ and the quartz frequency is $16 \mathrm{MHz}$.

The microcontroller of the Arduino Uno development platform composition is programmed via a USB cable using the specialized software Arduino 1.6.6, which is compatible with Windows operating systems.

The reading, processing and transmission of the weather data from the 8 sensors is based on a software program written in Arduino 1.6.6.

Once checked, this program is included in the composition of microcontroller memory ATMega328P Arduino platform.

The Arduino Uno platform is supplied with $12 \mathrm{Vdc}$ directly to the battery from the composition of the photovoltaic system (see figure 2). The sensors used in a meteorological station were chosen so that they 
be compatible with the development platform. The main features of the elements constituting the meteorological system and how to connect them are presented below [5-16]:

- The barometric pressure sensor. In order to measure the barometric pressure in the meteorological station, using a piezoresistive sensor, very accurate, BMP180, manufactured by Bosch Company. To offset the effects of temperature on the pressure, the BMP180 sensor is composed of a temperature sensor as well. This sensor is compatible with Arduino Uno platform and is powered by $3.3 \mathrm{Vdc}$ directly on the platform Arduino. How to connect the Arduino Uno platform BMP180 sensor is shown in figure 7 . The barometric pressure measurement range is from $300 \mathrm{HP}$ to $1100 \mathrm{hPa}$.

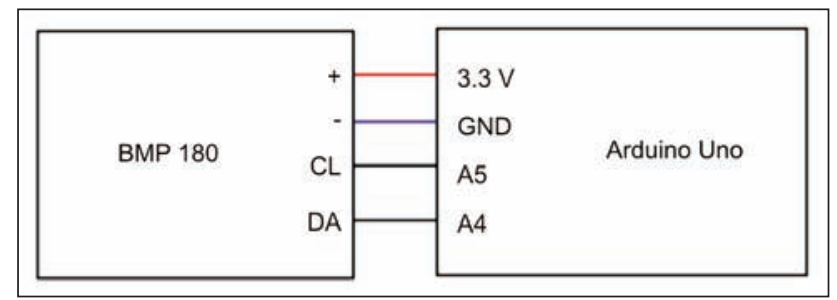

Fig. 7. How to connect the Arduino Uno sensor platform BMP180

The altitude is calculated using the following barometric formula:

$$
A=44330 \cdot\left(1-\left(\frac{p}{p_{0}}\right)^{\frac{1}{5.255}}\right)
$$

where $p_{0}=1013.25[\mathrm{hPa}]$ is the pressure of the sea level, $A[\mathrm{~m}]$ - altitude, and $p[\mathrm{hPa}]$ - the pressure measured with the use of BMP180 sensor.

Data communication between sensor and BMP 180 Arduino Uno platform development is based on I2C communication protocol.

- The humidity and temperature sensor.

Temperature and humidity sensor, used in a SHT15 meteorological station, produced by Sensirion Company $[17,18]$. SHT15 sensor platform is compatible with the Arduino Uno, being charged to $5 \mathrm{Vdc}$ directly on Arduino platform. How to connect the sensor to the platform SHT15 Arduino Uno is shown in figure 8.

The humidity measuring range is between $0[\% \mathrm{RH}]$ and $100[\% \mathrm{RH}]$, with a precision of $\pm 2[\% \mathrm{RH}]$. On the other hand, the measurement range of the

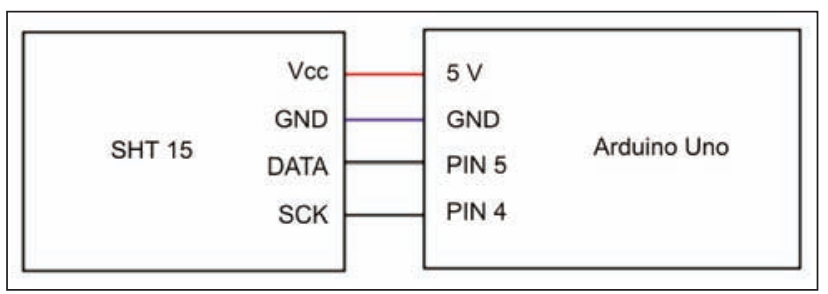

Fig. 8. The way the SHT15 sensor is connected to the Arduino Uno platform temperature is between $-40^{\circ} \mathrm{C}$ and $+123.8^{\circ} \mathrm{C}$, with a precision of $\pm 0.3^{\circ} \mathrm{C}$.

The communication of the data between SHT15 sensor and the Arduino Uno development platform is a made on serial protocol.

Pins 4 and 5 of the Arduino Uno platform structure (see figure 8) are digital input pins.

- The measuring element of the wind speed. Wind speed measurement is done using a N96FY anemometer. The anenometer used is conducted around three hemispheric cups mounted on a shaft, which are driven by the air currents. According to the technical specifications the anenometer is conducted around a reed relay which closes from a second to another, when the wind speed is 2.4 $\mathrm{km} / \mathrm{h}$. The way the anemometer is connected to the Arduino platform is shown in figure 9.

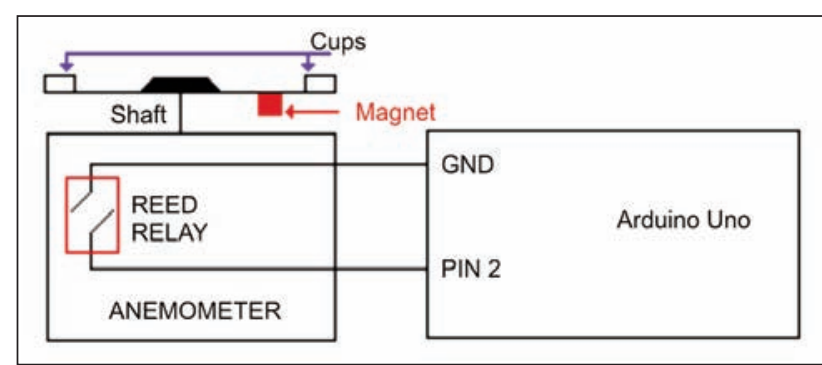

Fig. 9. The way the anemometer is connected to the Arduino Uno platform

Pin 2 of the Arduino platform structure (see figure 9) is a digital input pin. Pin 2, in the application, is configured to trigger an external interrupt on a falling edge of the input pulse.

The reverse logic counting of the pulses arriving on pin 2 is due to pull-up resistor that connects via terminal 2 at $5 \mathrm{Vdc}$ supply voltage of the composition of Arduino Uno platform.

- The element of measuring the wind direction. The wind direction, within a meteorological station is measured using a wind vane. The wind vane is made by means of eight resistances and 8 reed relays as in figure 10 .

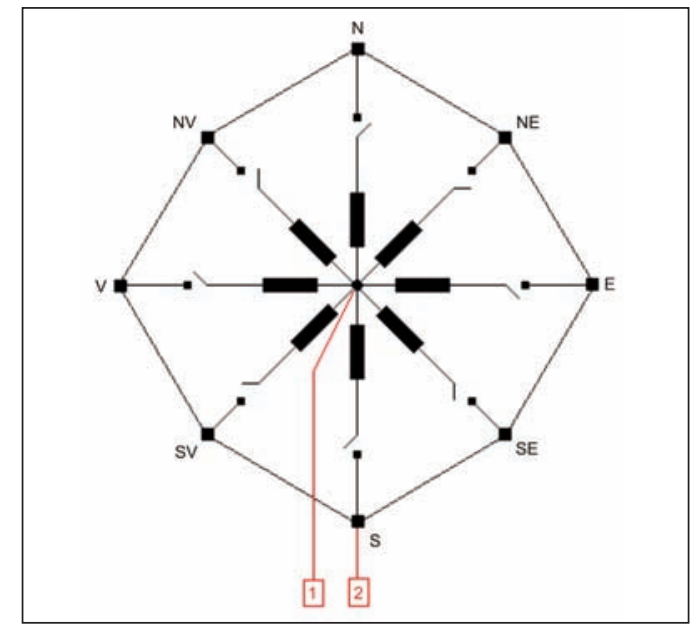

Fig. 10. The internal structure of the wind vane 
According to technical specifications, the wind vane is able to show 16 distinct directions of the wind. Besides the 8 resistors, the wind vane contains a fixed resistance, which together with the 8 resistors, form a resistive divider.

In these conditions, for every wind direction, the wind vane provides a voltage that is read on one of the analog inputs of the Arduino platform. How to connect a wind vane Arduino platform is shown in figure 11.

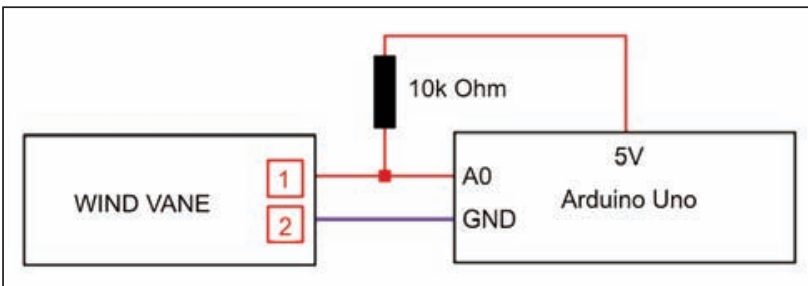

Fig. 11. Connection of the wind vane to the Arduino Uno platform

The A0 pin used for connecting the wind vane to the Arduino Uno platform, it is an analog one.

- The measurement element of the precipitations. The amount of precipitation that falls in a given area is monitored using a rain gauge. According to the technical specifications, the rain gauge is designed around a reed relay, which is activated every 0.2794 [mm]. The amount of precipitations is measured in [mm] thick layer of water (a thick layer 1 [mm] corresponds to a quantity of 1 [L] of water, spread evenly over an area of $\left.1\left[\mathrm{~m}^{2}\right]\right)$. The way the rain gauge is connected to the Arduino Uno platform is shown in figure 12.

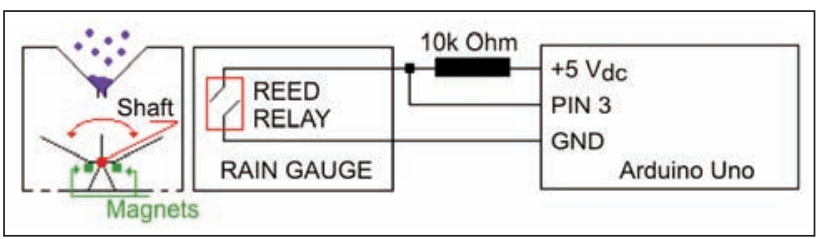

Fig. 12. The way the rain gauge is connected to the Arduino Uno platform

The pin 3 of the Arduino Uno platform structure (see figure 12) is a digital input pin and is configured as pin 2 in connection from the anenometer scheme (see figure 9).

- The measurement element of the solar radiation. The solar radiation measurement is made through a pyranometer, LP Silicon - PYRA 04, manufactured by Delta OHM, Italy. According to technical specifications, the feature of the pyranometer is a linear one with deviations of less than $1 \%$. The voltage provided by the PYRA 04 pyranometer is amplified in a voltage range $(0 \ldots 5)$ [V] through HD978TR4 circuit. The range measurement of the solar radiation sensor specific of the PYRA 04 is $(0 \ldots 2000)\left[\mathrm{W} / \mathrm{m}^{2}\right]$ having a sensitivity of $20\left[\mu \mathrm{V} /\left(\mathrm{W} / \mathrm{m}^{2}\right)\right]$. According to technical specifications, the static characteristic of HD978TR4 circuit is a linear one. The resolution of HD978TR4 circuit is $20[\mu \mathrm{V}]$ and the input voltage range is $(0 \ldots 20)[\mathrm{mV}]$. The way the pyranometer is connected through HD978TR4 circuit to the Uno Arduino platform is shown in figure 13.

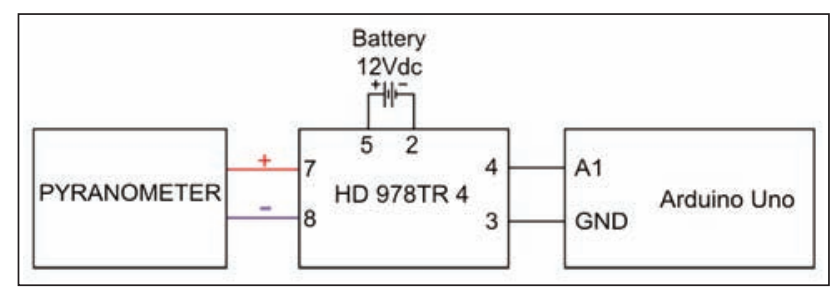

Fig. 13. The way the pyranometer is connected through HD978TR4 circuit to the Uno Arduino platform

The A1 pin used for connecting the PYRA 04 pyranometer to the Arduino Uno platform is an analog pin. The Arduino Uno platform analogues pins are connected to an analog-digital converter that has a resolution of 10 bits.

- The GSM modem in the composition of a weather station. Data transmission measured by sensors in the composition of meteorological station to the central computer is done via a GSM modem. The GSM modem used in a GSM weather station is a-gsm v2.064. This modem is compatible with Arduino Uno platform and connects directly to the terminal platform (the connection is via the 16-father pins of the modem that plugs directly into the mother pins of the Arduino Uno platform). The modem is fed through +5 [V] and GND pins of the Arduino Uno platform. Transmitting data from a weather station to the GSM modem of central computer componence is made using SMS messages. Data transmission is done when a transmission command is received from the modem of the central computer component. The data transmission is done every hour.

- The GSM modem of the central computer constituent. The data reading from all the weather stations is made using a GSM modem connected to a computer. The data obtained from the weather stations are stored on the central computer's hard disk, within Excel documents. The GSM modem from the constituent of the central computer is BGS2T Cinterion, manufactured by Germalto Company in Germany. The supply voltage of the modem is between $(8 \ldots 30)\left[\mathrm{V}_{\mathrm{dc}}\right]$ and the communication between the modem and the computer is via RS232 serial interface. The antenna used for modem BGS2T is one of nickel, of $2 \mathrm{~dB}$, covering the frequency bands 850, 950 and $1900 \mathrm{MHz}$ with an impedance of 50 [ $\Omega$ ]. The data acquisition program provided by the weather stations is conducted in Matlab and based on AT commands of the BGS2T modem.

\section{DESCRIPTION OF THE SOFTWARE}

The monitoring and transmission of data from sensors in the constituent of the meteorological stations 
is implemented in the ATMega328P microcontroller, constituting the development platform Arduino Uno. Each station of the meteorological system is identified by the telephone number of the GSM modem agsm v2.064.

On the other hand, the central computer system from the weather is identified by the telephone number of the modem BGS2T composition.

The data acquisition from a specified weather station and their transmission to the central computer is done only when the ATMega328P microcontroller receives a command transmission in this regard.

The order of transmission is an SMS message as follows: "TRANSMISSION START".

Upon receiving an order from meteorological data transmission program of the ATMega328P microcontroller constituent, it verifies that the phone number from which the message was received is identical to the composition BGS2T modem, connected to the central computer.

If the phone number is the same, it proceeds to the purchase, and then data transmission to the central computer via SMS.

The program of the ATMega328P microcontroller constituent is based on the flowchart in the following figure.

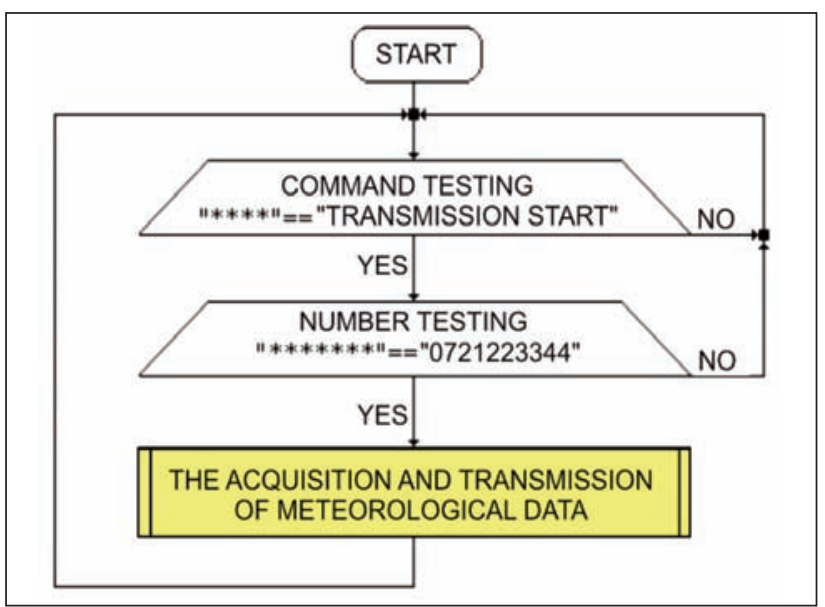

Fig. 14. The program flow diagram of the ATMega328P microcontroller constituent

The constituting elements of the weather stations are interrogated in a certain order.

On the other hand, the SMS message containing all of the data acquired from a specific weather station is composed of the values of the acquired placed in the message in the following order: the ambient temperature, intensity of solar radiation, humidity, barometric pressure, altitude, wind speed, wind direction and rainfall.

Each value in the composition of SMS is followed by an empty space. On the other hand, the monitoring of all the weather stations, running on the central computer, is based on the following flowchart.

From figure 15, it is noted that the reading and saving of the data constituent from a weather station, is the result of tests consisting of the verification telephone

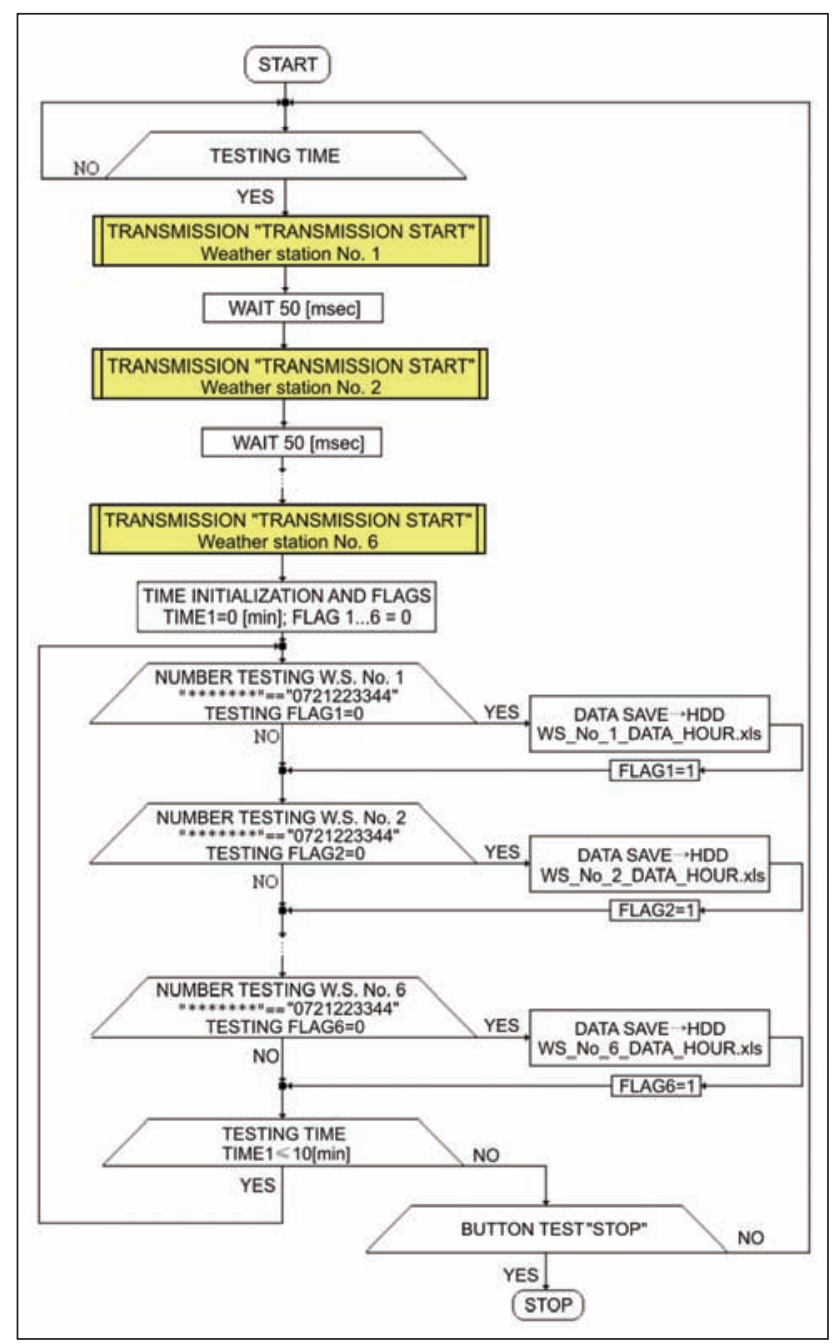

Fig. 15. The flowchart of the program constituting the central computer

number from the constituent of the meteorological station and of a flag.

The procedure for reading and saving the weather data is done in a loop that lasts 10 minutes.

The meteorological data are saved on the central computer's hard disk in some Excel documents. The name of the Excel documents it is given by the meteorological station, followed by the date and time the data is saved.

Meteorological data acquisition program can be stopped if the button "STOP" of the user interface is pressed.

The user interface and procurement program is realized in Matlab [19]

The meteorological data acquisition program is an executable type that can be installed on any Windows operating system of 32-bit.

The executable program is based on the MATLAB command "deploytool".

The user interface of the meteorological data acquisition program is shown in figure 16.

Starting the acquisition of meteorological data is done via the START button in the user interface structure (see figure 16).

The user interface is designed to monitor six meteorological stations. 


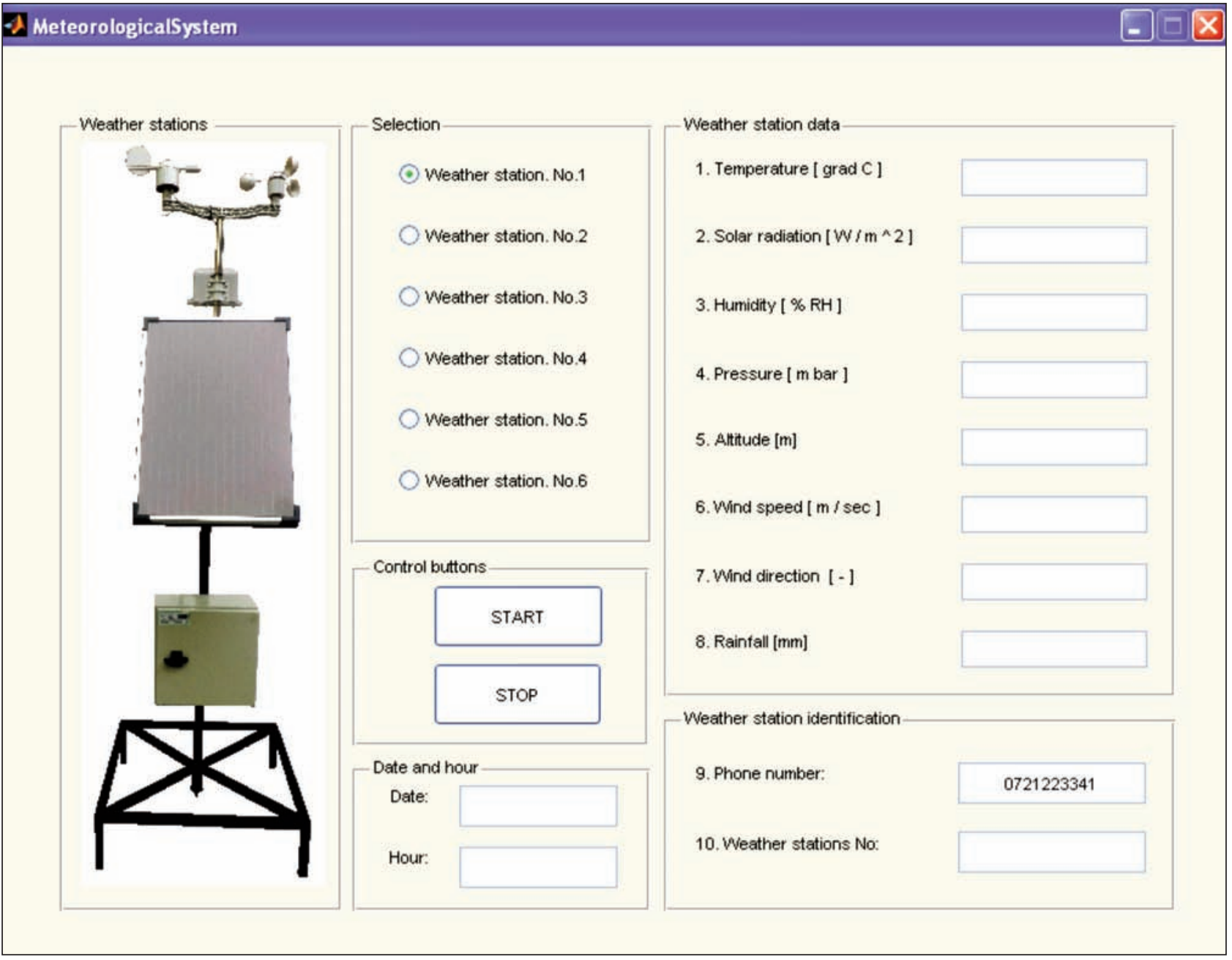

Fig. 16. The user interface of the software purchase

To view the latest values acquired, the interface has six radio buttons. Through these buttons, it can be selected at a time those six weather stations.

The parameters measured by the meteorological station, selected through the assigned radio button, are displayed to the right of the graphic interface in figure 16

Identifying the meteorological station selected is highlighted in the graphic interface through the telephone number and the number associated with it (number $k$ for the meteorological station $k$ ). On the other hand, for the user program to know the date and time the last meteorological data were received, the interface has two edit boxes, where the above information is displayed.

The program can be extended very easily for more weather stations.

\section{EXPERIMENTAL RESULTS}

With the six weather stations and acquisition program outlined above, it was performed an analysis of the meteorological data measured during the year 2014 in the city of Petrosani.

The six meteorological stations were located in the city of Petrosani at an altitude of about $618 \mathrm{~m}$.
For all weather variables, with the exception of wind direction, the average value was calculated based on values from the six weather stations. The average value of a variable has been calculated in the following way:

$$
V_{k}=\frac{1}{6} \cdot \sum_{i=1}^{6} V_{k, i} ; k=\{1,2, \ldots, 8\}-\{7\}
$$

where:

$V_{k}$ is the average number of variable weather $k$ and $V_{k}$ the weather variable number $k$ measured with the use of the meteorological station $i$. Variations during 2014 of the averages of the meteorological variables are shown in the following figures.

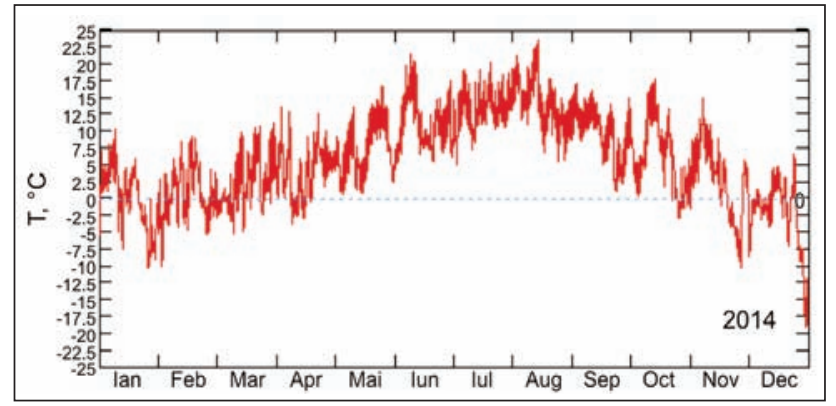

Fig. 17.The temparature variation during year 2014 


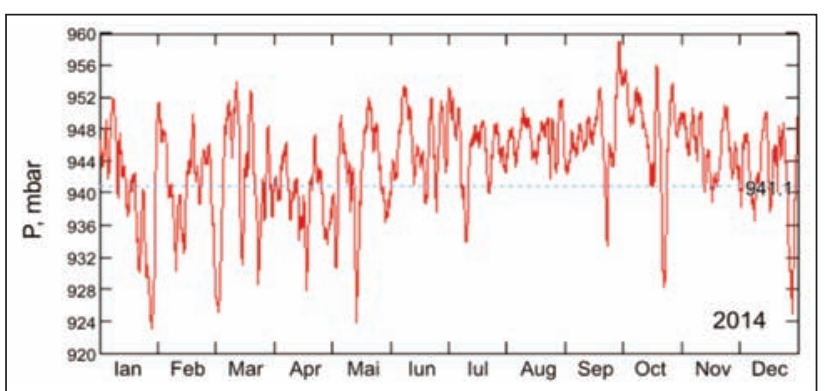

Fig. 18. The pressure variation during year 2014

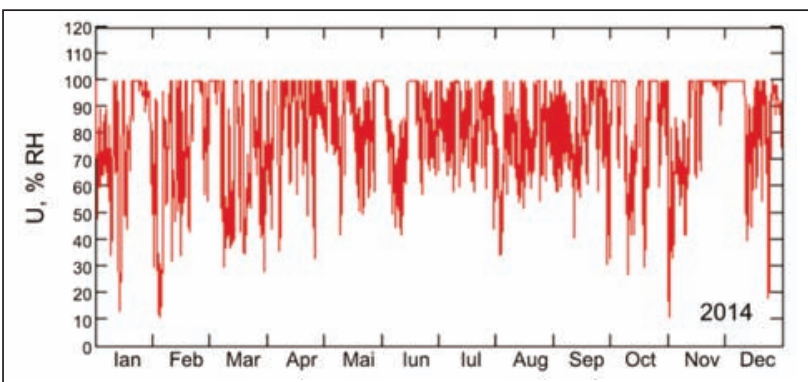

Fig. 19. The humidity variation during 2014

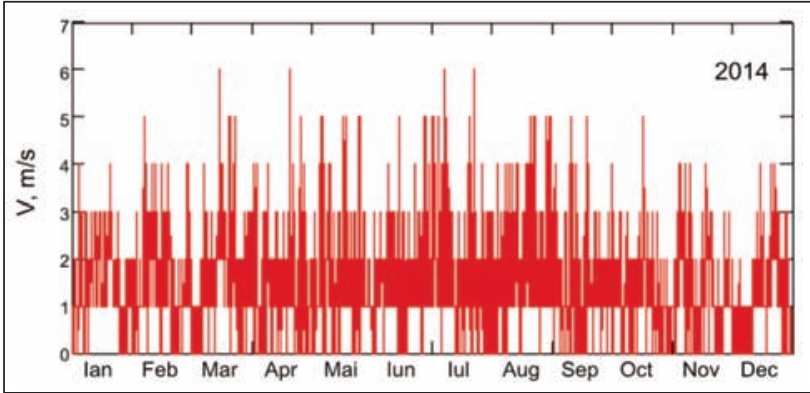

Fig. 20. The wind speed variation during 2014

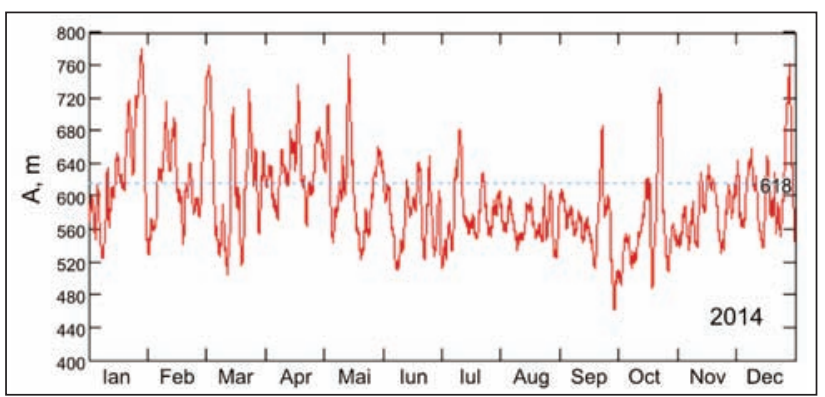

Fig. 21. The altitude calculated with the barometric formula

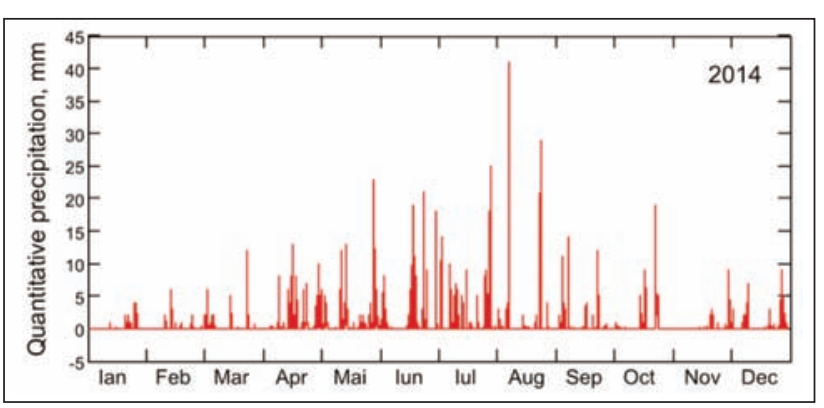

Fig. 22. The quantity of precipitation during year 2014

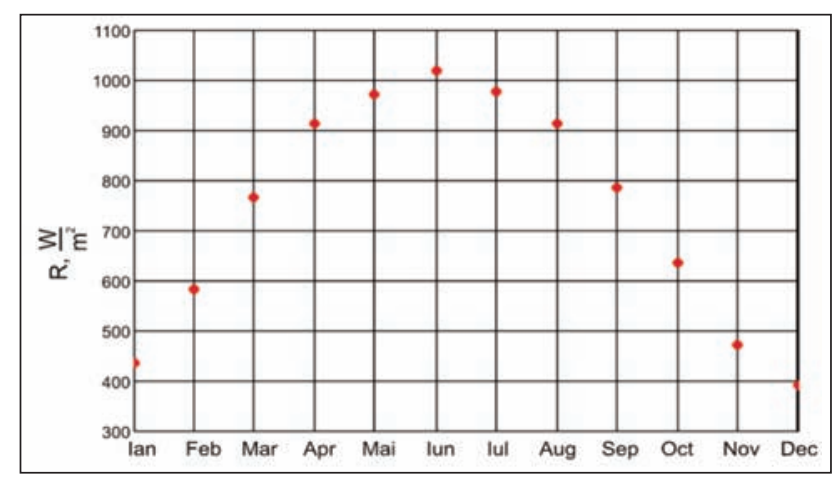

Fig. 23. The variation of the solar global radiation during year 2014

Global solar radiation during year 2014 falls in a horizontal plane, shown in figure 23 , is defined by the average monthly value of the maximum solar radiation measured every day.

After analyzing the above presented graphics the following conclusions were drawn:

\section{CONCLUSIONS}

1. The cold season in the city of Petrosani takes about 5 months (January, February, March, November and December) where the temperatures below zero degrees Celsius prevail. Winter thermal characteristics are influenced by air masses that are stagnating in Petrosani Depression. On the other hand, the maximum temperature in 2014 was $23.5^{\circ} \mathrm{C}$, recorded in August, while the minimum temperature of $-19.1^{\circ} \mathrm{C}$ was recorded at the end of December.

2. The warm season in the Petrosani depression lasts 3 months (June, July and August). During these three months, temperatures reach values above $20^{\circ} \mathrm{C}$. The thermal characteristics of the hot season are influenced by thermal inversions, phenomena that typically result in cool summers.

3. The barometric pressure during year 2014, presented variations around 941.1 [mbar], which corresponds to an altitude, calculated using the barometric formula 618 [m].

4. After analyzing the meteorological data measured, it was observed that during year 2014, in the city of Petrosani, south winds prevailed. On the other hand, it was noted that the air masses were stagnant over Petrosani, leading to maintain atmospheric pollutants. The air circuit in the Depression is done through Băniţa-Merisor lane (north) and Jiu Valley (south).

5. After analyzing data on wind speed during 2014, it was observed that the average speed was about $1.5[\mathrm{~m} / \mathrm{s}]$, in a southerly direction. On the other hand, it was observed that wind speed in Petrosani depression is increased with together with the altitude. On the mountain tops of Petrosani Depression, wind speed can exceed the $7[\mathrm{~m} / \mathrm{s}]$ value.

6. The amount of rainfall during year 2014 was not a uniform one. The maximum level of precipitations was reached in early August and was 41 [mm]. 
Regarding the average monthly amount of rainfall, we can say that the peak was reached in July and the minimum in January.

7. The average humidity during year 2014 was around $82[\% \mathrm{RH}]$. The maximum monthly average humidity was in December and the minimum in March.
8. The global solar radiation measured under blue sky in a horizontal plane reaches a maximum of $1020\left[\mathrm{~W} / \mathrm{m}^{2}\right]$ in June. On the other hand, the lowest values of solar radiation were recorded at the end and beginning of 2014. Thus, in December the solar radiation was of $391\left[\mathrm{~W} / \mathrm{m}^{2}\right]$, and in January it was $436\left[\mathrm{~W} / \mathrm{m}^{2}\right]$.

\title{
BIBLIOGRAPHY
}

[1] Tiţa, M.C. Atmospheric dispersion modeling of pollutants, AGIR Scientific Bulletin, 2012, no. 2, pp. 70-75.

[2] ***, Technical documentation of TPS-103 photovoltaic panel, www.conrad.com

[3] ***, Technical documentation of Conrad 12V/4A load controller, www.conrad.com

[4] ***, Technical documentation of S12/6.6S solar battery, www.Ipelectric.ro

[5] ***, Technical documentation of Arduino Uno platform, www.arduino.cc

[6] ***, Technical documentation of ATMEL microcontroller, ATMega328P, www.atmel.com

[7] ***, Technical documentation of BMP180 sensor, www.bosch-sensortec.com

[8] ***, Technical documentation of SHT15 sensor, www.sensirion.com

[9] ***, Technical documentation of N96FY anemometer, www.maplin.co.uk

[10] ***, Technical documentation of N96FY wind vane, www.maplin.co.uk

[11] ***, Technical documentation of N96FY rain gauge, www.maplin.co.uk

[12] ***, Technical documentation of LP Silicon - PYRA 04 pyranometer, www.deltaohm.com

[13] ***, Technical documentation of HD978TR4 circuit, www.deltaohm.com

[14] ***, Technical documentation of a-gsm v2.064 modem, http://itbrainpower.net

[15] ***, Technical documentation of BGS25 modem, www.gemalto.com

[16] ***, BGS25 AT comands manual, www.gemalto.com

[17] Petrilean, D. C., Irimie, S. I. Solutions for the capitalization of the energetic potential of sludge collected in Danutoni Wastewater Treatment Plant, In: Journal of environmental protection and ecology, ISSN 1311-5065, vol. 16, no. 3, pp. 1203-1211, 2015.

[18] Petrilean, D. C., Popescu F. D. Temperature determination in hydrotechnical works as a variable of the energy change between air and environment, In: Wseas Transactions nn Heat and Mass Transfer, ISSN: 1790-5044, Issue 4, Volume 3, pp. 209-218, 2008.

[19] Ghinea, M., Fireteanu, V. Matlab Numerical calculus. Graphics. Applications, Teora Publisher, 2004.

\author{
Authors: \\ Dr. Eng. NICOLAE DIACONU 1 \\ Prof. Dr. Eng. MARIN SILVIU NAN ${ }^{2}$ \\ Assoc. Prof. Dr. Eng. OLIMPIU STOICUTA ${ }^{3}$ \\ PhD student ANDREEA ROXANA UNGUR (POPESCU) ${ }^{4}$ \\ $P h D$ student MARIUS RAZVAN POPESCU ${ }^{4}$ \\ Dr. Eng. DANUT GRECEA ${ }^{5}$ \\ ${ }^{1}$ Petrila City Hall
}

2University of Petrosani, Faculty of Mechanical and Electrical Engineering, Department of Mechanical Engineering, Industrial Engineering and Transportation

${ }^{3}$ University of Petrosani, Faculty of Mechanical and Electrical Engineering, Department of Control Engineering,

Computers, Electrical Engineering and Power and Power Engineering

${ }^{4}$ Şcoala Doctorală a Universităţii din Petroşani

5 INCD-INSEMEX Petrosanu

Petrosani - 332006

Str. Universitatii, No. 20, jud. Hunedoara, Romania

e-mail: diaconu_primarie@yahoo.com; nan.marins@gmail.com; stoicutaolimpiu@yahoo.com

Corresponding author:

NICOLAE DIACONU

e-mail: diaconu_primarie@yahoo.com 